\title{
Ground Zero mosque in the context of America's post-9/11 religious pluralism: CDA of mainstream news media's coverage of the discursive event
}

\author{
Saad Boulahnane \\ Hassan II University, Casablanca Morocco \\ E-mail:saad.boulahnane@fulbrightmail.org \\ DOI: 10.18326/ijims.v8i2. 253-279
}

\begin{abstract}
This article analyzes the Ground Zero Mosque discursive event and the discourses surrounding the American Muslim Community and explores the role of the media in the production and reproduction processes of anti-Muslim frames. To understand Islamophobia in the United States in the context of religious pluralism, this article adopts Critical Discourse Analysis, under which two theories unfold: sourcing theory and framing theory. The sourcing analysis targeted the media voices monitoring the discourses and contributing to the discursive construction and interpretation of mosque proposal into an agenda-led image. The second theory is framing, which consists of including a perceived reality-in the news-, making it more salient, and presenting it to the audience. The data analyzed were collected from CNN and Fox News via Lexis Nexis online academic database. A total of 225 media transcripts- $(\mathrm{n}=138)$ Fox News and $(n=87) C N N-$ constituted the text and were coded and analyzed using Atlas.ti data mining software program. The critical analysis has resulted in a number of 180 voices-e.g. journalists, politicians, academics, officials,
\end{abstract}


etc. - contribution of the discursive construction of the non-violence event, of which 150 were anti-Muslim activists, journalists, politicians, reportedly former Muslim Brotherhood member, etc. The study has also resulted in two main frames: frame of illegitimacy and frame of terrorism, transforming the nonviolence event into a celebrated violent one, thereby providing a vivid image of America's project of religious pluralism and its capacity to accommodate the religions existing within the American confines.

Artikel ini menganalisis peristiwa acara diskursif Masjid Ground Zero dan wacana seputar Komunitas Muslim Amerika dan mengeksplorasi peran media dalam proses produksi dan reproduksi bingkai anti-Muslim. Untuk memahami Islamophobia di Amerika Serikat dalam konteks pluralisme agama, artikel ini mengadopsi Analisis Wacana Kritis, di mana dua teori terungkap: teori sumber dan teori framing. Analisis sumber menargetkan suara-suara media yang memonopoli wacana dan berkontribusi pada konstruksi diskursif dan interpretasi proposal masjid ke dalam pencitraan yang dipimpin oleh suatu agenda. Teori kedua adalah framing, yang terdiri dari memasukkan realitas yang dirasakan - dalam berita-, membuatnya lebih menonjol, dan menyajikannya kepada pemirsa. Data yang dianalisis dikumpulkan dari CNN dan Fox News melalui database akademik online Lexis Nexis. Sebanyak 225 transkrip media$(\mathrm{n}=138)$ Fox News dan $(\mathrm{n}=87) \mathrm{CNN}-$ merupakan teks dan dikodekan dan dianalisis menggunakan program perangkat lunak data mining Atlas.ti. Analisis kritis telah menghasilkan sejumlah 180 suara - misalnya wartawan, politisi, akademisi, pejabat, dll. - berkontribusi terhadap konstruksi diskursif dari peristiwa non-kekerasan, yang 150 di antaranya adalah aktivis anti-Muslim, jurnalis, politisi, mantan anggota Ikhwanul Muslimin, dll. Studi ini juga telah menghasilkan dua kerangka utama: bingkai illegitimacy dan bingkai terorisme, yang mengubah peristiwa non-kekerasan menjadi peristiwa yang sangat kejam. Inilah gambaran yang jelas tentang proyek pluralisme agama Amerika dan kapasitasnya untuk mengakomodasi agama-agama yang ada dalam batas-batas Amerika.

Keywords: Islamophobia; Ground zero;Sourcing; Religious pluralism; Framing 


\section{Introduction}

The 2010 Ground Zero mosque proposal represents a milestone in the relationshipof American mainstream news media and the American Muslim Community. The Ground Zero Mosque, or Cordoba House, was part of the Cordoba Initiative, of which the goalwas to spreadinter-religious acceptance and tolerance in the American public space according to Imam Feisal Abdul Rauf, although it received various cynical interpretations from different stakeholders.For instance, the projectname and goal were ascribed tothe idea of building a mosque on the ruins of Christian churches as a celebration of Islamic conquest of the West.Other agendachanneled readings purveyed negative frames associating the proposal with the context of $9 / 11$ and reducing it into a shock to the $9 / 11$ victims' families. The proposaltriggered a rapid emergenceof anti-Muslim voices and accusations about the Imam behind the proposal being a supporter of al-Qaeda. ${ }^{1}$ Other anti-Muslim organizations intensified the debate about the limits of Islam in America by engaging other texts, images, and discourses from the 9/11 attack repertoire. Certain Jewish organizations expressed disapproval of the plan to build the Islamic center, considering that the project would desecrate what amounted to a graveyard. ${ }^{2}$

The demagogic discourses preluded a nationwide disapproval and resentment on the part of many Americans. A 2010 Rasmussen Reports ${ }^{3}$ poll explored people's reactions to the proposed plan and found that only 20\% favored the construction of a mosque near the 9/11 Ground Zero site in New York City against a majority of $54 \%$, who overtly

${ }^{1}$ Alex Kane \& Steve Rendall, "The Media's Construction of the Ground Zero Mosque”. Retrieved from https://www.commondreams.org/views/2010/10/07/ medias-construction-ground-zero-mosque.

${ }^{2}$ Michael Barbaro. Debate Heats Up About Mosque Near Ground Zero. Retrieved in 8/1/2010 from http://freerepublic.com/focus/f-news/2562779/posts.

${ }^{3}$ Rasmussen Reports, Toplines - Mosque (July 1, 2010). 
opposed the project, leaving 26\% to uncertain answers. Another report by Political Research Associates ${ }^{4}$ stated that building an Islamic institution in Manhattan pushed triggered disturbing levels of antiMuslim rhetoric in the public space, with people shown holding signs with blood dripping "Sharia Law."Not only was opposition articulated at $64 \%$,discrepancies among political trends also unfolded, with $56 \%$ of Democrats against $76 \%$ of those who identified as republicans opposing the project. ${ }^{5}$ Further polls showedsimilar results. ${ }^{6}$ Despite the final public opposition, a dilemma regarding whether to vote for religious freedom or oppose the freedom emerged. While New York City voters admitted the legal position of the proposal, they considered the construction insensitive due to its association with the contextof terrorism. ${ }^{?}$

\section{Religious pluralism}

Religious pluralism constitutes the confines within which this article investigates media's discursive framing of the mosque proposal event. Investigating Islamophobia in the United States equally takes into account the celebrated character of religious pluralism, which transcends the mere recognition of the diversity of religions and ethnicities. Religious pluralism is not limited to mere "tolerance and a commitment to insure the rights of the followers of all faith traditions but the active effort to understand difference and commonality through dialogue ${ }^{8}$ "The American public space is characterized by a plurality of cultural and religious traditions in every part of the world. However, while diversity

${ }^{4}$ Thomas Cincotta, Manufacturing the Muslim Menace: Private Firms, Public Servants, and the Threat to Rights and Security, Somerville, MA: Political Research Associates, 2011.

${ }^{5}$ Fox News, Opinion dynamics, Poll (August, 2010).

${ }^{6} \mathrm{CNN}$, Opinion Research, Poll (August, 2010).

${ }^{7}$ Quinnipiac University Polling Institute, "9/11 Family Concerns Outweigh Muslim Right To Mosque, New York State Voters Tel”, Poll (2010).

${ }^{8}$ Julia C Hemeyer, Religion in America, New York: Routledge-Taylor \& Francis, 2016,7. 
is a given, constituted by the variety of cultural elements in society, pluralism remains an achievement. ${ }^{9}$ Debates on the delicate nuances distinguishing the terms plurality and pluralism and which characterizes the American public space have been raised by a number of researchers, e.g. James Beckford, who prefers the term diversity to describe a degree of homogeneity in society. ${ }^{10}$ Others prefer the term plurality, in part for its consistency with the term pluralism, which is different, given its higher form of plurality (or diversity). Pluralism can therefore be defined as the social arrangement and the treatment of religions in society by lawwhether equally or unequally. ${ }^{11}$

This article attempts to study the discursive strategies adopted in the framing of Ground Zero mosque event and the ideological construction of the American Muslim identity. It also seeks to understand the de facto application of plurality/pluralism in the American social and public space, of which the validity can only be measured on the basis of their positioning in media's spotlight. How the American people and American mainstream media reacted to the proposal to build a mosque was a reflection of not only the core values of the American public spacedescribed in religious pluralism-but also the attitudes, prejudice, and Islamophobia seen in this context in refusal and denial of rights as well as right to existence within the American society. This article therefore positions the Ground Zero proposal as a discursive event erected on the debris of not only remnants of terrorism but also post-9/11 Islamophobia.

\footnotetext{
${ }^{9}$ Diana L. Eck, On Common Ground: World Religions in America, Cambridge, MA: The Pluralism Project, 2008.

${ }^{10}$ Giuseppe Giordan \& Enzo Pace, Religious Pluralism: Framing Religious Diversity in the Contemporary World, Cham: Springer International Publishing, 2014, 51-52.

${ }^{11}$ Robert Jackson, Rethinking Religious Education and Plurality: Issues in Diversity and Pedagogy, London: Routledge, 2013; Jan Platvoet, Pluralism and Identity: Studies in Ritual Behaviour, Leiden: Brill, 1995.
} 
CAIR defines Islamophobia as close-minded prejudice against, or fear of Islam and Muslims. When we were formulating our definition, the goal in our mind was to differentiate between people who are just asking: what is this Islam thing, given that most Americans were introduced to Islam on 11/9 watching airplanes hit buildings. So close-minded is more of a reflection of the people with whom there is no conversation there and who are simply interested in smearing Islam and pushing it out of the country. ${ }^{12}$

\section{Research method}

To analyze media discourses and frames, relevant TV broadcast transcripts were collected from Lexis Nexis online academic database. As mentioned in the sampling part below, CNN and Fox News broadcast transcripts pertaining to Ground Zero mosque (park 51) event were retrieved from online search engine LexisNexis Academic during the period of July 1, 2010 and September 30, 2010. After logging onto the academic search engine, I used Power Search, which is an advanced search mode, using the following keywords: ground zero OR park51 AND Mosque. I specified the date between 01/07/2010 and 30/09/2010," and I selected "By type: Broadcast Transcripts" in Source. Then I searched. In the results showed: News Transcripts $>$ CNN Transcripts $(n=87)$; Fox News Network Transcripts $(n=138)$. The results yielded a total of 245 unfiltered broadcast transcripts, with 20 units being web-based publications, which were not included in the analysis since they were not displayed on TV, hence absence of mass exposure. After manually filtering the results, 138 Fox News transcripts and 87 from CNN, totaling 225 transcripts, were analyzed.

12 Face-to-face Interview with Corey Saylor, Director of the Department of Islamophobia-Council On American Islamic Relations-on February 5, 2015 in Washington. 
Table 1 The sampling

\begin{tabular}{lll}
\hline $\begin{array}{c}\text { Keyword enteredin } \\
\text { search engine }\end{array}$ & Sampling frame & \multicolumn{1}{c}{$\begin{array}{c}\text { Total transcripts } \\
\text { returned (225) }\end{array}$} \\
\hline $\begin{array}{l}\text { 'Ground zero mosque' } \\
\text { OR 'Park51 mosque' }\end{array}$ & $\begin{array}{l}\text { Fom: July 1 st }, 2010 \\
\text { To: Sept 30 } 0^{\text {th }}, 2010\end{array}$ & $\begin{array}{l}\text { Fox News (138) CNN } \\
(87)\end{array}$ \\
\hline
\end{tabular}

The coding of the collected data engaged word-by-word and statementby-statement analysis using Atlas.ti-a qualitative data-mining program. ${ }^{13}$ It consisted in identifying the repetitive meanings in the text and creating summative codes denoting the recurring semantic patterns. ${ }^{14}$ The collected codes are selected for the analysis stage, which engages Critical Discourse Analysis.

Analysis of the text is informed by two theories under Critical Discourse Analysis, i.e. sourcing theory and framing theory. The two theories represent the backdrop against which the selected codes are interpreted.

Choice of CNN and Fox News was based on the networks in question representing two of the most influential mainstream news media in the United States, according to a Brookings Institute study. Exposure to Fox News and misinformation on certain issues was also found to correlate, leading the public to endorse deviant opinions about Muslims and Islam. ${ }^{15}$ The two channels have shown constant interest in issues related to Muslims, Islam, and other Islam-associatedissues, including

${ }^{13}$ De Gregorio, Francesco Arcidiacono E, and Sheila Padiglia, Techniques D'analyse Qualitative: Le Logiciel Atls.ti, Saarbrücken: Editions universitaireseuropéennes, 2015.

${ }^{14}$ Johhny Saldaña, The Coding Manual for Qualitative Researchers, London: Sage Publications Ltd., 2015.

${ }^{15}$ Robert Jones, Daniel Cox, William Galston, and E J. Dionne. What It Means to Be American: Attitudes in an Increasingly Diverse America Ten Years After 9/11. 2011. Retrieved from https://www.prri.org/research/what-it-means-to-be-american/ 
Sharia, Bin Laden, Hamas, Jihad, Al-Qaida, etc. These factors indicate that misinformation or agenda-oriented coverage of Muslim news leads to a large portion of the American public endorsing negative opinions about American Muslims. For context, a recent study has shown that direct exposure to Fox News causes a rightward shift in the viewers' attitudes, which translates into the altering of the viewers' propensity to vote for republican candidates. ${ }^{16}$

\section{Media and journalism}

Journalism and journalists draw interpretative frameworks from their society's cultural repertoire, serving simultaneously as the producers, distributors and re/producers of public discourse ${ }^{17}$, which grants the media the position of a carrier for ideology and a very powerful tool for the dissemination of ideology through discourse ${ }^{18}$. Prior to discussions of journalistic practice and performance, "understanding the expectations about journalism's societal role and how such a position evolved" grants itself as a priority. The discourse of the media is considered the interface for the elite to practice their social domination and present itself as the self-appointed voice of the people, hence the voice of society. Therefore, media-the press in particular-becomes a powerful institution capable of empowering those who monitor it and granting them the possibility to impose a policy of exclusion on minorities or any social group that

\footnotetext{
16 Gregory J. Martin \& Ali Yurukoglu, "Bias in Cable News: Persuasion and Polarization”, American Economic Review, volume 107, issue 9 (2017), 2566-2568.

${ }^{17}$ Stuart Hall, "Representation, Meaning \& Language", in Hall S. (ed.), Representation: Cultural Representations and Signifying Practices, Milton Keynes/London: The Open University \& Sage Publications Ltd. 1997.

18 (Billig, 1995; Bishop and Jaworski, 2003; Chouliaraki, 1999; Madianou, 2005 cited in Talaat Pasha, "Islamists in the Headlines: Critical Discourse Analysis of the Representation of the Muslim Brotherhood in Egyptian Newspapers", Dissertation, the University of Utah, 2011.
} 
does not belong to what van Dijk labels as 'us' group. An example of the power of the press is noted in Henry and Tator's study of racism, which reveals that most of what the 'Whites' in the U.S. and Europe know about minorities and immigrants comes from the press. ${ }^{19}$ Through a critical discourse analysis of American news media transcripts, this article explores sourcing as media's powerful discursive strategy used in the reproduction of anti-Muslim discourses surrounding the mosque proposal. A CDA of sourcing will uncover the balancing of the news in an overarching context associated with tolerance and peace-that of religious pluralism. Through framing theory, the article will also analyze the major frames resulting from the discourses surrounding the Muslims in what became a discursive event in the American public space. The results will eventually be interpreted in light of religious pluralism and to what extent it associates with the American context. ${ }^{20}$

\section{Critical Discourse Analysis}

Critical Discourse Analysis allows for a systematic investigation targeting the opaque relationships of determination and causality between texts, events, discursive practices, and the wider social and cultural structures within which the events and texts exist. ${ }^{21} \mathrm{CDA}$ is also an approach capable of adopting other perspectives and methods in analyzing the relationship between language and social context $\mathrm{t}^{22}$. It is a critical perspective taking

19 Frances Henry and Carol Tator, Discourses of Domination: Racial Bias in the Canadian English-Language Press, Toronto: University of Toronto Press, 2016. https:// doi.org/10.3138/9781442673946.

${ }^{20}$ John O'Sullivan, Jane Suiter, and Dawn Wheatley, "Sourcing the Story: Journalistic Practices and Online News Coverage of Irish Healthcare Policy", Thesis, Dublin City University, School of Communications, 2018.

${ }^{21}$ Norman Fairclough, "Critical Discourse Analysis and the Marketization of Public Discourse: the Universities”, Discourse EF Society, volume 4, issue 2 (1993), 133-168.

22 Wei Wang, "Newspaper Commentaries on Terrorism in China and Australia: A Contrastive Genre Study', Ph.D. thesis, University of Sydney 
IJIMS: Indonesian Journal of Islam and Muslim Societies, Volume 8, Number 2, December 2018: 253-279

social problems as its focus, particularly the role of discourse in a process in which power abuse and domination are produced and reproduced. ${ }^{23}$

\section{Sourcing theory}

The sociology of news has placed the interactions between the journalist and the source under the spotlight; while some research studies have reviewed the patterns showing journalists as gatekeepers monitoring access into news discourse, ${ }^{24}$ others have employed a diversity of more sophisticated methodologies to better construe the interactions occurring between the journalist and the source. ${ }^{25}$ Journalists and the media are involved in selecting the sources of information to be quoted and heard, hence an overt sign of media's overwhelming reliance on officials for validation. ${ }^{26}$ The interactions between the journalist and the source are patterned practices; which source to appear in the news stories is significant in the news discourse because of the source's pragmatic and the symbolic functions. ${ }^{27}$

\section{Lexical words as an auxiliary to CDA}

Analyzing a discursive event entails a linguistic analysis at the level of vocabulary, grammar, semantics, and other cohesion-organization above

Faculty of Education and Social Work, 2006.

${ }^{23}$ T. A van Dijk, "Multidisciplinary CDA: a Plea for Diversity", in R. Wodak, \& M. Meyer (Eds.), Methods of Critical Discourse Analysis, London: SAGE Publications Ltd., 2001, 95-121.

${ }^{24}$ Manning D. White, "The 'gate Keeper': a Case Study in the Selection of News", Journalism Ë Mass Communication Quarterly, volume 27, issue 4 (1950): 383-390.

25 Bob Franklin, Journalists, Sources, and Credibility: New Perspectives, New York: Routledge, 2013.

${ }^{26}$ Norman Fairclough, Critical Discourse Analysis: The Critical Study of Language, London: Routledge, 2013.

${ }^{27}$ Roger Fowler, Language in the News: Discourse and Ideology in the Press, London; New York: Routledge, 1991. 
the sentence level to understand the way discourses are organized, articulated, and made to appear unquestionable. ${ }^{28}$ One of the examples underlying the influential effect of the text's lexical choices and lexicalization is noun pairing, e.g. freedom fighter vs. Terrorist, etc. ${ }^{29}$ Analysis of lexical choices engages the study of separate lexical items and how they can denote or connote an idea differently from how another word would denote or connote if placed in the same position. This process is ideology driven. ${ }^{30}$

\section{Framing theory}

Framing consists in "selecting some aspects of a perceived reality and [making] them more salient in a communicating text." ${ }^{31}$ It is also the "schemata of interpretation," which consists in including and excluding certain aspects in order to give a situation certain meanings. ${ }^{32}$ The frames that are visible in the media tend to uncover the broad dynamics wherein a topic is negotiated. ${ }^{33}$ Another definition views framing as the "information presented to an audience and how the selection of one

${ }^{28}$ Norman Fairclough, Critical Discourse Analysis: The Critical Study of Language, London: Routledge, 2013.

${ }^{29}$ Kress, 1983; Van Dijk 1995; Clark 1998 cited in Talaat Pasha, "Islamists in the Headlines: Critical Discourse Analysis of the Representation of the Muslim Brotherhood in Egyptian Newspapers”, Dissertation, the University of Utah, 2011.

30 Puleng Thetela, "Critique Discourses and Ideology in Newspaper Reports: A Discourse Analysis of the South African Press Reports on the 1998 SADC's military intervention in Lesotho", Discourse and Society, volume 12, issue 3 (2001), 347-70.

31 Regula Hanggli and Kriesi Hanspeter, "Political Framing Strategies and Their Impact on Media Framing in a Swiss Direct-Democratic Campaign", Political Communication, volume, 27, issue 2 (2010), 145.

32 Erving Goffman, Frame Analysis: An Essay on the Organization of Experience, Cambridge, Mass: Harvard University Press, 1974.

${ }^{33}$ Jonah Berger, "Word of Mouth and Interpersonal Communication: a Review and Directions for Future Research", Journal of Consumer Psychology, volume 24, issue 4 (2014), 586-607. 
IJIMS: Indonesian Journal of Islam and Muslim Societies, Volume 8, Number 2, December 2018: 253-279

method or content of presentation over another affects how an audience perceives a person, event, or issue." ${ }^{34}$

\section{Sourcing analysis}

As mentioned in the theoretical framework, sourcing constitutes one of the strategies used in and by media to purportedly achieve objectivity. However, since this objectivity is forced by authoritative voices, the idea of sourcing authority voices has been adopted as a powerful strategy serving media's agenda. For instance, while public discourse is controlled by politicians, media discourse is under the control of journalists and those sourced in a certain discursive event. Sourcing analysis finds itself, as part of CDA with the same endeavour, in the position of untangling the invisible forms of power.

Well, I would really like to jump in, and I would say, on 11/9, it didn't take a mosque for extremists to come and attack the World Trade Center and kill my brother.(...)I was very fearful for the security of New York. I mean, when I lost my brother, I couldn't believe, you know, that there were such extremists in the world. ${ }^{35}$ (Rosaleen Tallon, Sister of fire fighter killed on September 11).

Rosaleen Tallon is one of the most sourced individuals across the coverage of the present news. Her visibility, either in person or via recorded video tape, accounts for her capacity as a close relative of a 9/11 victim. This visibility is instrumental in perpetuating the anti-Muslim via the account of terms like terror, 9/11, Islamic violence, killing, etc. Her discourse is made to represent the $9 / 11$ victims and their families and

\footnotetext{
${ }^{34}$ Melissa J. Gonzalez, "Media Propaganda: A Framing Analysis of Radio Broadcasts from U.s. to Cuba", Thesis, University of South Florida, 2013, 17.

35 Ground Zero Mosque Controversy; Pakistan Flood Disaster Far from Over; Looking Ahead in Pakistan; National Guard Vets Battle to Find Jobs; Spectators Killed in Off-Road Race in California; Finding New Tech Gadgets for School. [Transcript, Television broadcast]. (August 15, 2010 Sunday). CNN, Retrieved from www.lexisnexis. com/hottopics/lnacademic
} 
echoes for its emotional side.

We have to remember also that the father of this imam was kicked out of Egypt because of his involvement with the Muslim Brotherhood. He was in the Muslim Brotherhood with Ayman al-Zawahiri, the second man in charge of al Qaeda (Brigitte Gabriel).

Brigitte Gabriel is another Lebanese-American conservative activist and president of Act! for America-an organization funded by anti-Muslim organizations in the context of the "industry of Islamophobia ${ }^{36}$." In 2011, she oversaw a compensation of $\$ 156,473$ for spreading negative rhetoric about Muslims, according to a study by Council On American Islamic Relations. ${ }^{37}$ The quote alludes to two unfounded claims: one that the Imam's father was involved with the Muslim Brotherhood and that of the Muslim Brotherhood being a terrorist group. Brigitte Gabriel was also listed in a report by Council on American Islamic Relations as one of the worst 2009-2010 inductees for their contributions to Islamophobia and intolerance towards Islam and Muslims. One of her statements about Islam and Muslims were: "every practicing Muslim is a radical Muslim" and "America and the West are doomed to failure in this war unless they stand up and identify the real enemy - Islam." 38

Well, look, I mean, Anwar al Awlaki was a terrorist who condemned terrorism on MPR and PBS. Now, are we saying that Anwar al Awlaki, who never committed really a terror attack, he never blew up a bomb in America, can we say that Anwar al Awlaki can build a mosque on the World Trade Center? And the whole idea of saying that Faisal Abdul Rauf is peaceful is a bunch of nonsense ${ }^{39}$ (Walid Shoebat).

${ }^{36}$ Council on American-Islamic Relations (CAIR), Legislating fear: Islamophopia and its impact in the United States, Report 2013.

${ }^{37}$ Council on American-Islamic Relations (CAIR) Report 2013.

${ }^{38}$ Council on American-Islamic Relations (CAIR) Report 2013, 17.

${ }^{39}$ Fox News Network. Top Story. (August 27, 2010). Retrievedfrom www.lexisnexis. com/hottopics/lnacademic 
IJIMS: Indonesian Journal of Islam and Muslim Societies, Volume 8, Number 2, December 2018: 253-279

As a member of ICTOA, which stands for International CounterTerrorism Officers Association, Walid Shoebat is another influential anti-Muslim activist. He is also and a self-proclaimed former member of Muslim Brotherhood, which he conveys as former Islamic fundamentalist. Shoebat is a keynote speaker in a number of counter-terrorism agencies specialized in courses on countering terrorists. ${ }^{40}$

This is not a constitutional issue. This is not a religious liberties issues. This is a matter of common decency. And we have to -- we have this extraordinary sensibility to the demands of the Muslim world, and there's no reciprocity. If he was genuine -- if he was genuine in wanting to improve the image of Islam, he would move that mosque. It is an insult. It is deeply offensive, sir. Deeply offensive. And it is deliberately -- deliberately provocative ${ }^{41}$ (Pamela Geller).

Pamela Geller is another authoritative activist disapproving of the American Muslim community's proposal. Her renowned book Atlas Shrugs about Muslims being terrorists and rapists has been banned in a few countries for the atrocities associated with Muslims. She is also renowned for her anti-Muslim bus ads in New York seeking to spread hate and misconceptions about Muslims. Geller was among the worst 2009-2010 inductees for frequently contributing to Islamophobia and intolerance towards Muslims, according to a report issued by CAIR. ${ }^{42}$

It was a very simple question. Do you believe, along with Feisal Abdul-Rauf, that there should be restrictions on freedom of speech and Sharia Islamic

${ }^{40}$ Thomas Cincotta, Manufacturing the Muslim Menace: Private Firms, Public Servants, and the Threat to Rights and Security, Somerville, MA: Political Research Associates, 2011; Kamal Saleem and Lynn Vincent, The Blood of Lambs: A Former Terrorist's Memoir of Death and Redemption, London: Simon and Schuster, 2017.

${ }^{41}$ Faiz Shakir, REPORT: \$42 Million From Seven Foundations Helped Fuel The Rise of Islamophobia In America, retrieved from https://thinkprogress.org/report42-million-from-seven-foundations-helped-fuel-the-rise-of-islamophobia-in-america$3 \mathrm{e} 55497 \mathrm{~d} 4455 /$

${ }^{42}$ Council on American-Islamic Relations (CAIR) Report 2013. 
law in the United States with the stonings, and the amputations, and the oppression of women, and the warfare against unbelievers? (Robert Spencer).

Author of 18 books on Islam and radicalism, ${ }^{43}$ Robert Spencer runs Jihad watch-an organization operating within the "industry of Islamophobia" ${ }^{44}$-a network encompassing funded activists e.g. Pamela Geller, Brigitte Gabriel, Robert Spencer, WalidShoebat, Frank Gaffney, David Horowitz,etc. according to Council on American Islamic Relations (CAIR) and Thomas Cincotta. Robert Spencer was too listed in CAIR's report aboutthe worst American anti-Muslim activists. ${ }^{45}$

Here's what has been under the surface in America for a long time. You have a lot of Americans looking a lot of the Muslim community -- the vast majority of the Muslim community both overseas and here refuse to condemn Hamas, who refuse to condemn Hezbollah, who even while they condemn the violence on 11/9 don't condemn the reason for the violence on 11/9 (Rick Santorum, (R) Former Pennsylvania Senator). ${ }^{46}$

As former senator from Pennsylvania, former presidential candidate, attorney, and Republican Party politician, Rick Santorum represents a highly authoritative source of information. As expressed in his statement, it is assumed that the vast majority of Muslims did not condemn the violence on September $11^{\text {th }}$ and that they do not condemn Hamas, which he considers a terrorist group. He has also referred to Sharia as America's existential threat and defended the ethnic and religious profiling, of which the first target are the Muslims.

\section{The numerical visibility of the sourced voices}

${ }^{43}$ Robert Spencer, "Why Jihad Watch?" Jihad Watch, https://www.jihadwatch.org/ why-jihad-watch

${ }^{44}$ Nathan Lean, The Islamophobia Industry: How the Right Manufactures Hatred of Muslims, London: Pluto Press, 2017.

${ }^{45}$ Council on American-Islamic Relations (CAIR) Report 2013.

${ }^{46}$ Fox News Network, "Controversial Imam Representing U.S." (August 2010). https://www.catholic.org/news/politics/story.php?id=37787 
IJIMS: Indonesian Journal of Islam and Muslim Societies, Volume 8, Number 2, December 2018: 253-279

Analysis of the 225 transcripts has turned a total of 180 voices sourced in the interpretation of the Ground Zero/Park51 mosque proposal with a clearly disparate distribution of voices, leading to an unbalanced news frame. This unfair distribution-characterized by the abundant visibility of anti-mosque voices-indicates the magnitude of the framed product resulting from media sourcing strategy. The infrequency of neutral or proMosque activists and the little media coverage led to the poor visibility of discourses of righteousness and law afar from ideological aims related to fundamentalism, threat, terrorism, etc. The numerical representation of the sourcing imbalance was articulated at $(n=150)$ anti-mosque voices across Fox News and CNN against $(=30)$ voices endorsing a legal or pluralist discourse. The disparity characterizing Fox News and CNN's discursive strategy is shown in the table below:

Table 2 The distribution of the sourced voices across the two networks combined

\begin{tabular}{lll}
\hline \multicolumn{1}{c}{ Sourced voices } & Total $(\mathrm{n}=180)$ \\
\hline Neutral/pro-mosque voices & $(\mathrm{N}=30)$ & \\
Anti-mosque voices & $(\mathrm{N}=150)$ & \\
\hline
\end{tabular}

Table 3. Lexical choice and associated discourses

\begin{tabular}{lrr}
\hline & Total term frequency & $\begin{array}{c}\text { Frequency per } \\
\text { transcript }\end{array}$ \\
\hline 9/11 & 864 & 3.84 \\
Extremis* & 216 & 0.96 \\
Hamas, Al Qaeda, Bin Laden & 417 & 1.85 \\
Intolerance & 63 & 0.28 \\
Jihad $^{*}$ & 102 & 0.45 \\
Radical $^{*}$ & 339 & 1.5 \\
Sharia $_{\text {Terror }}^{*}$ & 387 & 1.72 \\
Threat & 744 & 3.3 \\
Tolerance & 297 & 1.32 \\
\hline
\end{tabular}


This sub-section shows the lexical representation of the discourses interpreting the mosque proposal, and hence defining the intention and presence of the Muslims in the American public space. The terms and associated discourses led to frames of terrorism, extremism and radicalism. The terms were retrieved using Atlas.ti data mining software program with the auto-coding function to elicit words and their derivatives. The asterisk $\left({ }^{*}\right)$ is a functionality in the data mining program to request endings of the words entered. For example, searching the word extrem returns existing results the following words: extreme, extremist/s, and extremism.

The term terror and its derivatives (i.e. terrorist/s and terrorism) appeared 744 times during the Fox News and CNN coverage throughout the 225 transcripts, which accounts for the appearance of 3.3 terms in each transcript. Other violence-related terms like Hamas, Al-Qaeda, and Bin Laden were grouped on the basis of Fox News and CNN quoting Hamas and Al Qaedawith thesame agenda-Bin Laden is also considered a symbol of terrorism in the transcripts. A number of 417 appearances, of the three terms combined, were found, leading to a mean visibility of more than one term per transcript $(n=1.18)$.Similarly, the term radical and its derivatives (i.e. radicalism, radical, etc.) appeared abundantly in the text and forced a negative tone and imminent danger from the mosque construction. The visibility frequency was articulated at $(n=339)$, with three appearances per transcript. Extremism and extremist also recurred during the coverage resulting in a negative tone surrounding the news reporting-216 in total, appearing once per transcript (0.96).

Found associated with negative terms and contexts, Sharia was quoted to mark a negative tone in the text and to discursively form the event with the idea of a suspicious, terrorist, and jihadist agenda. The negative meanings attributed to Sharia emanate from the way the term 
IJIMS: Indonesian Journal of Islam and Muslim Societies, Volume 8, Number 2, December 2018: 253-279

was mentioned and the context in which it was inserted. The numerical representation of the term is $(n=387)$, with a mean visibility of more than two terms per transcript $(\mathrm{n}=1.72)$.

\section{Lexical choice in context}

In reaction to the proposal to build a mosque in New York, activist Pamela Geller said:

To what end? To take over America. And you can't negate the fact that the Muslim terrorists were yelling "Allah Akbar." ${ }^{\text {"47 }}$ (Pamela Geller, Stop Islamization of America)

Earlier you heard Congressman Louie Gohmert lay out a conspiracy theory involving Muslim terrorist babies. You saw pictures of protestors outside mosques, one of the groups planning to actually burn Korans on 11/9. You just hear a Christian minister say Islam is a lie - that's his words. ${ }^{48}$ (Anderson Cooper)

Attempted terror attacks aimed at the U.S. have come mostly from Muslim extremists_born outside of America. ${ }^{49}$ (Kiran Chetry)

In another ugly act of provocation, last year Jones distributed T-shirts that said "Islam is of the Devil." But this latest hateful stunt has attracted the attention of General David Petraeus. He says that the Taliban will use this for propaganda purposes and could endanger American troops fighting Islamic

${ }^{47}$ Dr. Laura Calls It Quits; Where Has Gulf Oil Gone?; Firestorm Grows Over Islamic Center Near GroundZero. [Transcript, Televisionbroadcast]. (August 17, 2010 Tuesday). CNN, Retrievedfrom www.lexisnexis.com/hottopics/lnacademic

${ }^{48}$ Terror Babies; Immigration Loophole - BirthTourists; Ground Zero Mosque Controversy; Protesting Muslims in America; Kids, Race \& Parenting; Turning Greener Bricks into Schools. [Transcript, Television broadcast] (August 11, 2010 Wednesday) CNN, Retrievedfrom www.lexisnexis.com/hottopics/lnacademic

${ }^{49}$ Fleeing Hurricane Earl: Earl Targets East Coast; The New Normal or New Frugality; Islamophobia in America; Palestinian and Israeli Peace Talks Happening at the State Department. [Transcript, Television broadcast], (September 2, 2010 Thursday) CNN, Retrieved from www.lexisnexis.com/hottopics/lnacademic 
terrorism around the globe. ${ }^{50}$ (Monica Crowley)

I will say that the Muslim terrorists_were practicing pure Islam, original Islam. The Turkish prime minister... ${ }^{51}$ (Pamela Geller)

Critical analysis of the lexical choice across the transcripts hasuncoveredthe negative terms drawing the confines of the cognitive interpretations of the discursive event. The examples above represent a sample of the lexical representation of the salient discourses. Concerningthe terms tolerance and intolerance,they are nottwo different words describing Muslims as either tolerant or intolerant; none of the terms associates Muslims with tolerance. While intolerant is a direct adjective describing Muslims as such, tolerance describes what the Muslims are not or lack. For example:

It is long past time for the Muslim world to show a little respect and tolerance to America. After all, Muslims attacked us in the name of Allah. ${ }^{52}$ Bill O'reilly The contextual investigation of the collected terms attempts to give a vivid idea of the terms in their context.

\section{The resulting salient discourses: the frames}

As mentioned in the theoretical framework, framing is a process during which the media suggest what to think about and how to think about it by rendering specific news items more salient than others. The resulting frames are labelled frame of Illegitimacy and frame of terrorism, which are composed of the totality of terms and discourses found.

${ }^{50}$ Church to Burn Korans on 9/11, [Transcript, Television broadcast] (September 7, 2010 Tuesday ). Fox News Network, Retrieved from www.lexisnexis.com/hottopics/lnacademic

${ }^{51}$ Ground Zero Mosque Controversy; Pakistan Flood Disaster Far from Over; Looking Ahead in Pakistan; National Guard Vets Battle to Find Jobs; Spectators Killed in Off-Road Race in California; Finding New Tech Gadgets for School. [Transcript, Television broadcast]. CNN. (August 15, 2010 Sunday). Retrieved from www.lexisnexis.com/hottopics/lnacademic

52 Talking Points Memo and Top Story. Fox News Network. (September 9, 2010 Thursday). Retrieved from www.lexisnexis.com/hottopics/lnacademic 
IJIMS: Indonesian Journal of Islam and Muslim Societies, Volume 8, Number 2, December 2018: 253-279

\section{The frame of illegitimacy}

With the authoritative voices and their overly anti-construction discourses, the Ground Zero mosque proposal, as a text, explained the proposal from the perspective of illegitimacy. The Islamic center was also construed as sharing a common ground with violence and terrorism. This particular framing took more than the traditional, linear onesource outlet; many sources were utilized in this ideological endeavor to construct and reinforce the idea about the proposal being an illegitimate right. The 9/11 victims' families were also referenced to feed the frame with an emotional tone. The media succeeded in discursively remaking the proposal into a wrong, unethical and immoral gesture on the part of the Muslim community. The mosque was therefore a misplaced initiative and indicative of the Muslim community's victory over the American victims, in particular, and the American people, in general.

\section{The frame of terrorism}

Since 2001, the abundance in violence-led and death-leading attacks has built a strong terminology of violence, terrorism, and threat-terms that represent the core omnipresent frames. When covered, Islam is made to correlate with violence and related topics. The frame of Terrorism has prevailed across the media and emerged via terms like 9/11, Hamas, Al Qaeda, Jihad, extremism, Sharia, etc. and both direct and indirect statements about the proposal being related to violence, fundamentalism, and even terrorism. The voices sourced in the news reporting, the lexical choice, and statements collected during the coding process have contributed to one summative frame interpreting the non-violence news as a terrorismdriven event. The terrorism frame was also listed in the Runnymede Trust report; Islam was perceived as "violent, aggressive, threatening, supportive 
of terrorism, engaged in 'a clash of civilizations" ${ }^{53}$.The outnumbering of pro-construction sources by those against also accounted for the imbalanced and unjust reporting of the Muslim community.

The idea construed behind the concluded frames can be seen in the Muslim community being set as an Other-"a silent figure or one whose narrative has been erased. ${ }^{54}$ "While the unquestionable reference to terrorism refers to fear and alienation, the idea of illegitimacy leans more towards a second-degree group whose voice has little resonance within the American public space.

\section{Conclusion}

This article has attempted to present the framing of Ground Zero Mosque event through the imbalanced sourcing strategy and the heavy visibility of negative terms feeding the anti-Muslim narrative, e.g. terrorism, extremism, Hamas, Sharia, Jihad, etc. Despite the non-violent nature of the news, media coverage channelled the proposal event through an antiMuslim agenda, resulting in the vivid othering of identity of American Muslims in the United States and the intensified ambiguity characterizing American religious pluralism. The Critical Discourse Analysis probed deeply into the latent discourses and the main discursive strategy adopted in maintaining the re/production of Islamophobia, which indicates that the sourcing imbalance and frames of terrorism and illegitimacy both feed on a pre-set glossary of Islam related to negative phenomena and strengthen the othered public discourse and opinion on the Muslim community. It is this continuous cycle that engraves the discourse and

\footnotetext{
${ }^{53}$ Runnymede Trust, Islamophobia: a challenge for us all, retrieved from https://www. runnymedetrust.org/companies/17/74/Islamophobia-A-Challenge-for-Us-All.html

54 Wening Udasmoro, "The Language Construction of Muslims As the Others in French Contemporary Discourses”, Indonesian Journal of Islam and Muslim Societies, volume 7, number 1 (2017), 82.
} 
IJIMS: Indonesian Journal of Islam and Muslim Societies, Volume 8, Number 2, December 2018: 253-279

the interpretation of whatever phenomenon confronting us as common sense.

As a challenging obstacle, Islamophobia poses a threat not only to American Muslims but also to America's celebrated characterreligious pluralism, which calls for a redefinition to the concept in light of the intensified censorship on Islam and Muslims in the American public space. As put forth by Steven Vertovec, ${ }^{55}$ the west's paradoxical inclinations towards American Muslims are articulated in how tolerance and acceptance of Muslims into the public domain are encouraged while simultaneously resisting the Muslim presence, faith, and practice of religion. This unsettled stance also relates to the notion of religious pluralism. Saad Boulahnane notes:

The American Muslim identity and its 'pending' status in the American public space [alludes] to an incomplete process of integration of the American Muslims as both Muslims and Americans. This process also raises scepticism about a fabric and a background that is integrative rather than assimilationist, against which the success of the religious pluralism project is measured. ${ }^{56}$

It is therefore understood from the situation of minorities that the validity of America's religious pluralism can only be confirmed when these minorities can "rest not only tolerated and welcomed but also embraced in the mosaic fabric deemed constitutive of today's United States of America." 57

55 Steven Vertovec, "Islamophobia and Muslim recognition in Britain", in Haddad Y. Y. (ed.), Muslims in the West from Sojourners to Citizens, Oxford: Oxford University Press, 2002.

${ }^{56}$ Saad Boulahnane, "A two-stage Islamophobia: The American Muslim Image between Integration and public 'estrangement' in Chapel Hill reporting”, Journal of Humanities and Social Sciences, volume 2, issue 1 (2018), 91.

${ }^{57}$ Saad Boulahnane, "A two-stage Islamophobia”..., 91. 


\section{Bibliography}

Barbaro, Michael, "Debate Heats Up About Mosque Near Ground Zero," 2010, Retrieved November 15, 2015, from http://www.nytimes. com/2010/07/31/nyregion/31 mosque.html?_r=0

Berger, Jonah, "Word of Mouth and Interpersonal Communication: a

Review and Directions for Future Research", Journal of Consumer Psychology, volume 24, issue 4 (2014): 586-607.

Boulahnane, Saad, "A two-stage Islamophobia: The American Muslim Image between Integration and public 'estrangement' in Chapel Hill Reporting", Journal of Humanities and Social Sciences, volume 2, issue 1 (2018): 81-93. http://dx.doi.org/10.26389/S171217.

Church to Burn Korans on 9/11, [Transcript, Television broadcast], (September 7, 2010 Tuesday). Fox News Network, Retrieved from www.lexisnexis.com/hottopics/lnacademic

Cincotta, Thomas. Manufacturing the Muslim Menace: Private Firms, Public Servants, and the Threat to Rights and Security. Somerville, MA: Political Research Associates, 2011.

CNN. Opinion Research. Poll. (August 11, 2010). Retrieved from http:// i2.cdn.turner.com/cnn/2010/images/08/11/rel11a1a.pdf

Council on American-Islamic Relations (Cair). Legislating fear: Islamophopia and its impact in the United States. Report. 2013. Retrieved from http://www.cair.com/images/islamophobia/Legislating- Fear.pdf

Dr. Laura Calls It Quits; Where Has Gulf Oil Gone?; Firestorm Grows Over Islamic Center Near Ground Zero, [Transcript, Television broadcast]. (August 17, 2010 Tuesday). CNN, Retrieved from www. lexisnexis.com/hottopics/lnacademic

Eck, Diana. On Common Ground: World Religions in America. Cambridge, MA: The Pluralism Project, 2008.

Fairclough, Norman, "CriticalDiscourseAnalysis and the Marketization of Public Discourse: the Universities", Discourse E Society, volume 4, issue 2 (1993): 133-168.

Fairclough, Norman. Critical Discourse Analysis: The Critical Study of Language. London: Routledge, 2013.

Fleeing Hurricane Earl: Earl Targets East Coast; The New Normal or New 
Frugality; Islamophobia in America; Palestinian and Israeli Peace Talks Happening at the State Department, [Transcript, Television broadcast], (September 2, 2010 Thursday), CNN. Retrieved from www.lexisnexis.com/hottopics/lnacademic

Fowler, Roger. Language in the News: Discourse and Ideology in the Press. London; New York: Routledge, 1991.

Fox News Network, Opinion dynamics. Poll. (August 13, 2010). Retrieved from https://www.foxnews.com/projects/pdf/081310_MosquePoll. pdf

Fox News Network, Top Story (August 27, 2010). Retrieved from www. lexisnexis.com/hottopics/lnacademic

Fox News Network, Top Story (August 27, 2010). Retrieved from www. lexisnexis.com/hottopics/lnacademic

Franklin, Bob. Journalists, Sources, and Credibility: New Perspectives. New York: Routledge, 2013.

Giordan, Giuseppe, and Pace, Enzo. ReligiousPluralism: FramingReligiousDiversity in the Contemporary World. Cham: Springer International Publishing, 2014.

Goffman, Erving. Frame Analysis: An Essay on the Organization of Experience. Cambridge, Mass: Harvard University Press, 1974.

Gonzalez, Melissa J., "Media Propaganda: A Framing Analysis of Radio Broadcasts from U.s. to Cuba", Thesis, University of South Florida, 2013.

Gregorio, De, Francesco Arcidiacono, Eugenio, and Padiglia, Sheila. Techniques D'analyse Qualitative: Le Logiciel Atls.ti. Saarbrücken: Editions universitaires européennes, 2015.

Ground Zero Mosque Controversy; Pakistan Flood Disaster Far from Over; Looking Ahead in Pakistan; National Guard Vets Battle to Find Jobs; Spectators Killed in Off-Road Race in California; Finding New Tech Gadgets for School [Transcript, Television broadcast], CNN. (August 15, 2010 Sunday). Retrieved from www.lexisnexis. com/hottopics/lnacademic

Hall, Stuart, "Representation, meaning\&language". In: Hall S (ed) Representation: Cultural representations and signifying practices. Milton 
Keynes, London: The Open University\& Sage Publications Ltd. 1997: 15-64.

Hanggli, Regula, and Hanspeter Kriesi, "Political Framing Strategies and Their Impact on Media Framing in a Swiss Direct-Democratic Campaign”, Political Communication, volume 27, issue 2 (2010): 141157.

Hemeyer, Julia C. Religion in America. New York: Routledge-Taylor \& Francis, 2016.

Henry, Frances, and Carol Tator. Discourses of Domination: Racial Bias in the Canadian English-Language Press. Toronto: University of Toronto Press, 2016.

Jackson, Robert. Rethinking Religious Education and Plurality: Issues in Diversity and Pedagogy. London: Routledge, 2013.

Jones, Robert P, Daniel Cox, William A. Galston, and E J. Dionne, "What It Means to Be American: Attitudes in an Increasingly Diverse AmericaTenYearsAfter 9/11". Retrieved from https:// www.brookings.edu/events/what-it-means-to-be-american-new-pollexplores-attitudes-in-an-increasingly-diverse-america/

Kane, Alex \& Rendall, Steve, "The Media's Construction of the 'Ground Zero Mosque”. Retrieved 3 April 2016, from http://fair.org/extra/ the-medias-construction-of-the-ground-zero-mosque/

Lean, Nathan. The Islamophobia Industry: How the Right Manufactures Hatred of Muslims. London: Pluto Press, 2017.

Martin, Gregory J. \& Yurukoglu, Ali, "Bias in Cable News: Persuasion and Polarization," American Economic Review, volume 107, issue 9 (2017): 2565-2599. Retrieved from http://www.nber.org/papers/ w20798.pdf

McPherson, James M., "A Fair Chance in the Race of Life: Thoughts on the 150th Anniversary of the Founding of the Columbia Institution", Sign Language Studies, volume 9, issue 1 (2008): 33-44. Retrieved 13 January 2016, from http://dx.doi.org/10.1353/sls.0.0006

O'Sullivan, John; Suiter, Jane; Wheatley, Dawn. Sourcing the Story: Journalistic Practices and Online News Coverage of Irish Healthcare Policy. Dublin City University: School of Communications, 2018. 
IJIMS: Indonesian Journal of Islam and Muslim Societies, Volume 8, Number 2, December 2018: 253-279

Retrieved from http://doras.dcu.ie/22175/

Pasha, Talaat, "Islamists in the Headlines: Critical Discourse Analysis of the Representation of the Muslim Brotherhood in Egyptian Newspapers", Dissertation, the University of Utah, 2011.

Platvoet, Jan. Pluralism and Identity: Studies in RitualBehaviour. Leiden: Brill, 1995.

Quinnipiac University Polling Institute, "9/11 Family Concerns Outweigh Muslim Right To Mosque, New York State Voters Tell”, Poll (2010).

Rasmussen Reports. “Toplines - Mosque.” (2010, July 1) Retrieved from http://www.rasmussenreports.com/public_content/ business/econ_survey_questions/july_2010/toplines_mosque_ july_19_20_2010

Runnymede Trust, Islamophobia: a challengefor us all, retrieved from https:// www.runnymedetrust.org/companies/17/74/Islamophobia-AChallenge-for-Us-All.html

Saldaña, Johnny. The Coding Manual for Qualitative Researchers. London: Sage Publications Ltd. 2015.

Saleem, Kamal, and Vincent, Lynn. The Blood of Lambs: A Former Terrorist's Memoir of Death and Redemption. London: Simon and Schuster, 2017. Spencer, Robert, "Why Jihad Watch?" Jihad Watch. Retrieved from www. jihadwatch.org

Terror Babies; Immigration Loophole - BirthTourists; Ground Zero Mosque Controversy; Protesting Muslims in America; Kids, Race \&Parenting; Turning Greener Bricks into Schools. [Transcript, Television broadcast]. (August 11, 2010 Wednesday) CNN. Retrieved from www.lexisnexis.com/hottopics/lnacademic

Thetela, Puleng, "Critique discourses and ideology in newspaper reports: A Discourse Analysis of the South African Press Reports on the 1998 SADC's military intervention in Lesotho", Discourse and Society, volume 12, issue 3 (2001): 347-70.

Thinkprogress, "Report: $\$ 42$ Million From Seven Foundations Helped Fuel The Rise Of Islamophobia In America”. Retrieved from http:// thinkprogress.org/politics/2011/08/26/304306/islamophobianetwork/ 
ThinkProgress, Frank Gaffney Braves Muslim Brotherhood Infiltration To Warn CPAC About Grover Norquist. Retrieved from http:// thinkprogress.org/politics/2011/02/13/143792/gaffney-cpac/

Udasmoro, Wening, "The Language Construction of Muslims As the Othersin French Contemporary Discourses”, Indonesian Journal of Islam and Muslim Societies, volume 7, number 1 (2017): 77-99.

van Dijk, T. A, "Multidisciplinary CDA: a Plea for Diversity", in R. Wodak, \& M. Meyer (Eds.), Methods of Critical Discourse Analysis. London: SAGE Publications Ltd., 2001: 95-121.

Vertovec, Steven, "Islamophobia and Muslim recognition in Britain", in Haddad, Y. Y. (ed.). Muslims in the West from Sojourners to Citizens. Oxford: Oxford University Press, 2002.

Wang, Wei, "Newspaper Commentaries on Terrorism in China and Australia: A Contrastive Genre Study', Ph.D. thesis, University of Sydney Faculty of Education and Social Work, 2006.

White, Manning D., "The "gate Keeper": a Case Study in the Selection of News", Journalism E Mass Communication Quarterly, volume 27, issue 4 (1950): 383-390. 
